\title{
Presentation a conceptual model to explain determinants of breakthrough the Islamic banking marketing: a managerial perspective
}

\author{
Seyed Reza Seyed-Javadin, Reza Raei, Mohammad Javad Iravani, \\ Mohammad Safari* \\ Faculty of Management, University of Tehran, Tehran, Iran \\ *E-mail address: m.safari@ut.ac.ir
}

\begin{abstract}
Taking advantage of applications of marketing in the Islamic banking is a great opportunity for this area to gain competitive advantage in the today's turbulent business and market. Specialized field of Islamic banking marketing is a subset of marketing management has received less attention and consideration. Islamic banking (IB) is one of the growing fields in the today's economy. To achieve more advancement in the IB it is necessary that recent findings of the other research and practical areas to be used and implemented. Scholars and experts believe that the market for Islamic banking has grown rapidly over the past few years, and this robust growth is expected to continue for the foreseeable future. In many markets, Islamic banking has evolved from being a niche offering into being part of the mainstream financial services landscape. Marketing capabilities can provide the convenient and required ground for the continued growth of Islamic banking. This study aimed at present a conceptual model to explain the determining factors to achieve the IB marketing from managerial perspective. Using a descriptive method this study tried to identify and present the main factors from managerial perspective that affected on the IB marketing. Proposed model and appropriated explanations have been provided in the paper.
\end{abstract}

Keywords: Islamic banking; financial services; marketing management; customers Islamic marketing

JEL Classification: G21, M1, M21, N25

\section{INTRODUCTION}

Islamic banking as a major center for financial transactions in Islamic societies plays a key role in the development of Islamic economics. Islamic banking system, grounded in ideology and values of Islamic economics and its realization requires establishment of social and economic justice and also equitable distribution of income and wealth in society (SeyedJavadin et al, 2014). The market for Islamic banking has grown rapidly over the past few years, and this robust growth is expected to continue for the foreseeable future.

In many markets, Islamic banking has evolved from being a niche offering into being part of the mainstream financial services landscape (Vayanos et al, 2008). The purpose of Islamic banking as a banking system is based on Islamic laws and also theories of economists and banking experts and scholars of Islam. So, if it's accepted that the basic components of 
Islamic banking are removing of usury (Riba) of all banking operations and compliance of these operations with Shariah, thus the basis of Islamic banking are including: profit sharing, clarifying the direction of resource using and supervision on the banking operations (SeyedJavadin et al, 2014).

In order to maintain the achievements of Islamic banking and also enhance this growth rate, it is required using the new findings of other sciences such as a powerful theoretical and practical filed namely marketing management and planning. Marketing is the process of communicating the value of a product or service to customers, for the purpose of selling that product or service. Marketing can be looked at as an organizational function and a set of processes for creating, delivering and communicating value to customers, and customer relationship management that also benefits the organization (Kotler \& Keller, 2009). Marketing management using its approaches and strategies focus on the customers in order to deliver valuable goods or services that finally lead to mutual satisfaction namely both firms or organization and customer. Also, as Kotler argues marketing management is the art and science of choosing target markets and getting, keeping, and growing customers through creating, delivering, and communicating superior customer value. In this study, the application of marketing management and planning and related capabilities in the Islamic banking is called as Islamic banking marketing. This study is tried to identify and explain the important factors as determinants in the IB marketing breakthrough in the form of a conceptual model. Accordingly, the basic research question underlying this study is that: what of the main factors determining the breakthrough of IB marketing?, and also, which model can explain it well?

\section{MARKETING MANAGEMENT: CONCEPTS AND ELEMENTS}

As newest defined by American Marketing Association (AMA) Marketing is the activity, set of institutions, and processes for creating, communicating, delivering, and exchanging offerings that have value for customers, clients, partners, and society at large. Also, as Kotler argues marketing management is the art and science of choosing target markets and getting, keeping, and growing customers through creating, delivering, and communicating superior customer value. Kotler's definition of marketing is as follow: Figure 1.

Marketing management is regarded to the responsibility for firm's efforts to promote products. Indeed, it is one of the main management disciplines, encompassing all the strategic planning, operations, activities, and processes involved in achieving organizational objectives by delivering value to customers. Marketing management focuses on satisfying customer requirements by identifying needs and wants, and developing products and services to meet them. Today's focus is on the long lasting relationships with customers and consumers to create value for firm/organization/corporation and customer. Thus, relationship marketing is in the heart of the marketing management planning and activities. The importance of developing and maintaining enduring relationships with customers of service businesses is generally accepted in the marketing literature. 


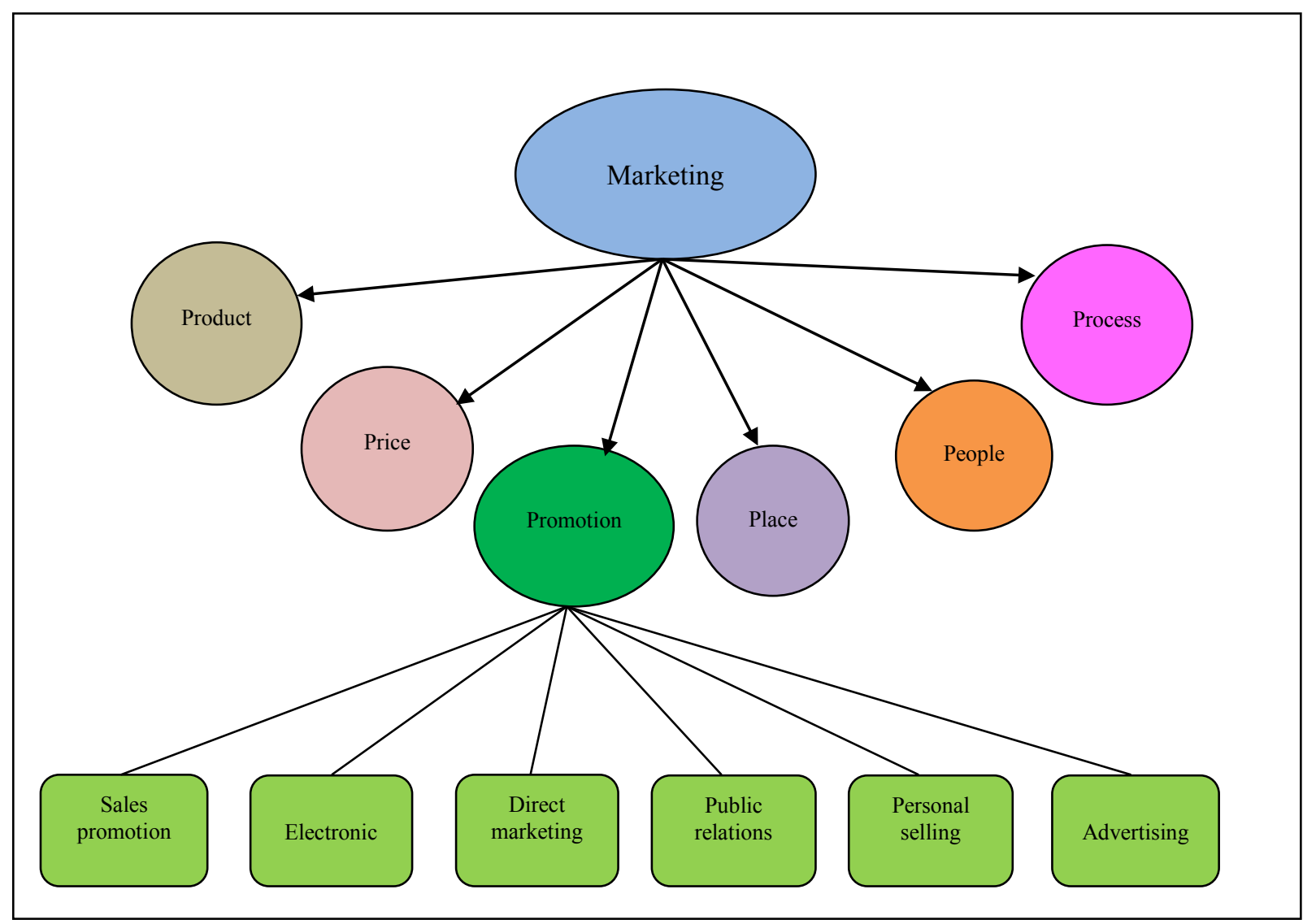

Figure 1. Kotler's definition of marketing.

The Islamic banking marketing is regarded as one of the crucial factors for developing and success of Islamic banking in the far scope time (El-Seoudi et al, 2012). The Islamic banks that have succeeded in providing marketing services and Islamic banking in a modern and high quality and in many ways. This proves to us the success of Islamic banks in the marketing of its services, and the ability of Islamic banks to compete with conventional banks in this area (El-Seoudi et al, 2012). A key challenge for researchers is to identify and understand how managerially controlled antecedent variables influence important relationship marketing outcomes (Hennig-Thurau et al, 2002). Creating long term relationship with customers is based on the many factors and dimensions. Two main of these factors are customer satisfaction and customer loyalty. Customer satisfaction and loyalty is two dimensions of the most important constructs in relationship marketing. In the new marketing era customer satisfaction is a main effective factor for long term behavior of customers. Also, loyalty of customers is lead to increase business value and remain business costs low as well. That means lower than the time when companies seek for new customers (Fathollahzadeh et al, 2011). Notably, to understand, satisfy and forecast needs of customers were considered most important competitive advantages for companies (Vilares and Coelho, 2003). Main other factors are effective on the relationship marketing that are quality, benefits that customers 
seek, awareness from IB services, commitment, confidence to the system, visibility, availability and ease of use.

\section{ISLAMIC BANKING: DEFINITION AND PROSPECT}

Islam is not simply one of the greatest monotheistic religions, signifying submission to the will of Allah, but as system of life in entirety. It prescribes a complete code of conduct for every day human life in all its spheres and manifestations. It does not confine itself to a spiritual relationship between man and Allah or describes the Almighty only with a transcendental reference but also regulates, in right proportions, an interactive relationship between man and man, and between man and society with moral, political and economic genesis (Memon, 2007). From a situation when it was virtually unknown, Islamic banking has expanded to become a distinctive and fast growing segment of the international banking and capital markets.

There are well over 200 Islamic banks operating in over 70 countries comprising most of the Muslim world and many Western countries (Hassan and Lewis, 2007). An Islamic banking and financial system exists to provide a variety of religiously acceptable financial services to the Muslim communities. In addition to this special function, the banking and financial institutions, like all other aspects of Islamic society, are expected to contribute richly to the achievement of the major socio-economic goals of Islam (Chapra, 1985). The theory of Islamic banking is based on the concept that interest is strictly forbidden in Islam, and that Islamic teachings provide the required guidance on which to base the working of banks. The basic principle that has guided all theoretical work on Islamic banking is that although interest is forbidden in Islam, trade and profit is encouraged (Gudarzi-Farahani \& Sadr, 2012). The most important mission of Islamic banks refers to establishing developed social and economic environment through the distribution of financial product and services that is in line with principle of Islam and Shariah (Metawa and Almossawi, 1998).

Islamic bank is an institution that mobilizes financial resources and invests them in an attempt to achieve predetermined islamically -acceptable social and financial objectives. Both mobilization and investment of funds should be conducted in accordance with the principles of Islamic Shariah. Accordingly, scholars and experts believe that basic principles of IB are: Prohibition of Interest or Usury, Ethical Standards, Moral and Social Values, and Liability and Business Risk. Also, it is sated that the basic principle in Islamic law is that exploitative contracts or unfair contracts that involve risk or speculation are impermissible. Under Islamic banking, all partners involved in financial transactions share the risk and profit or loss of a venture and no one gets a predetermined return. The market for Islamic banking has grown rapidly over the past few years, and this robust growth is expected to continue for the foreseeable future. In many markets, Islamic banking has evolved from being a niche offering into being part of the mainstream financial services landscape. At the same time, the competitive landscape is being redrawn, with more Islamic financial services institutions in the marketplace than ever before. Incumbent banks and new market entrants are facing vastly different market conditions and need to develop new sources of differentiation beyond compliance with Shariah (Islamic law) to compete or remain successful in the future (Vayanos et al, 2008).

Banking system and activities have a special and crucial status in Iran. Indeed, banking sector is the biggest body of Iranian service sector of economy (Safari \& Safari, 2012). SeyedJavadin et al (2014) in a research identified and prioritized the important challenges regarding 
to the Islamic banking system in I.R.Iran (Seyed-Javadin et al, 2014). Karbhari et al (2004) investigated the main problems, challenges, and opportunities facing Islamic banking system especially with focus on the United Kingdom. Estiri et al (2011) identified and extend the conceptualization and measurement of customer satisfaction in the Islamic banking sector in Iran. Jamshid and Hussin (2012) proposed a conceptual framework to explore factors that affect Islamic credit card adoption and usage by bank customers in Malaysia.

\section{DESIGN AND METHOD}

To achieve the research proposed model, using a descriptive method model's elements and dimensions have been extracted and presented. Descriptive studies are usually the best methods for collecting information that will demonstrate relationships and describe the world as it exists. These types of studies are often done before an experiment to know what specific things to manipulate and include in an experiment. Descriptive research generally precedes explanatory research. Descriptive research is used to describe characteristics of a population or phenomenon being studied. A descriptive study is one in which information is collected without changing the environment. Sometimes these are referred to as correlational or observational studies. After detailed literature review and also study the research background and some interviews, factors determining on the IB marketing have been extracted and presented. Then using experts required data has been gathered from the viewpoints of the scholars of the field that mainly focus on the managerial viewpoints in the banking sectors especially those have practically or theoretically in the IB and marketing.

\section{PROPOSED MODEL}

Based on the data and information collected, in this section the proposed model is presented. Totally in this model 15 elements are linked together to form the research framework. Nine basic factors are affected on the customer satisfaction that is including: Quality, Benefits, Awareness, Commitment, Confidence, Ease of use, Availability, Intention, and Visibility. Also, three basic elements are affected on the customer satisfaction, customer loyalty and customer value that are including: IT capabilities, Structure agility, and HR competencies. Figure 2 shows the research conceptual model and its relationships.

Table 1. Basic elements and factors of the research.

\begin{tabular}{|c|c|}
\hline Categories & Related factors and elements \\
\hline Category one factors & Quality \\
& Benefits \\
& Awareness \\
& Commitment \\
& Confidence \\
\hline
\end{tabular}




\begin{tabular}{|c|c|}
\hline & Ease of use \\
& Availability \\
& Intention \\
& Visibility \\
\hline Category two factors & customer satisfaction \\
& customer loyalty \\
\hline Category three factors & customer value \\
\hline & IT capabilities \\
& Structure agility \\
& HR competencies \\
\hline
\end{tabular}

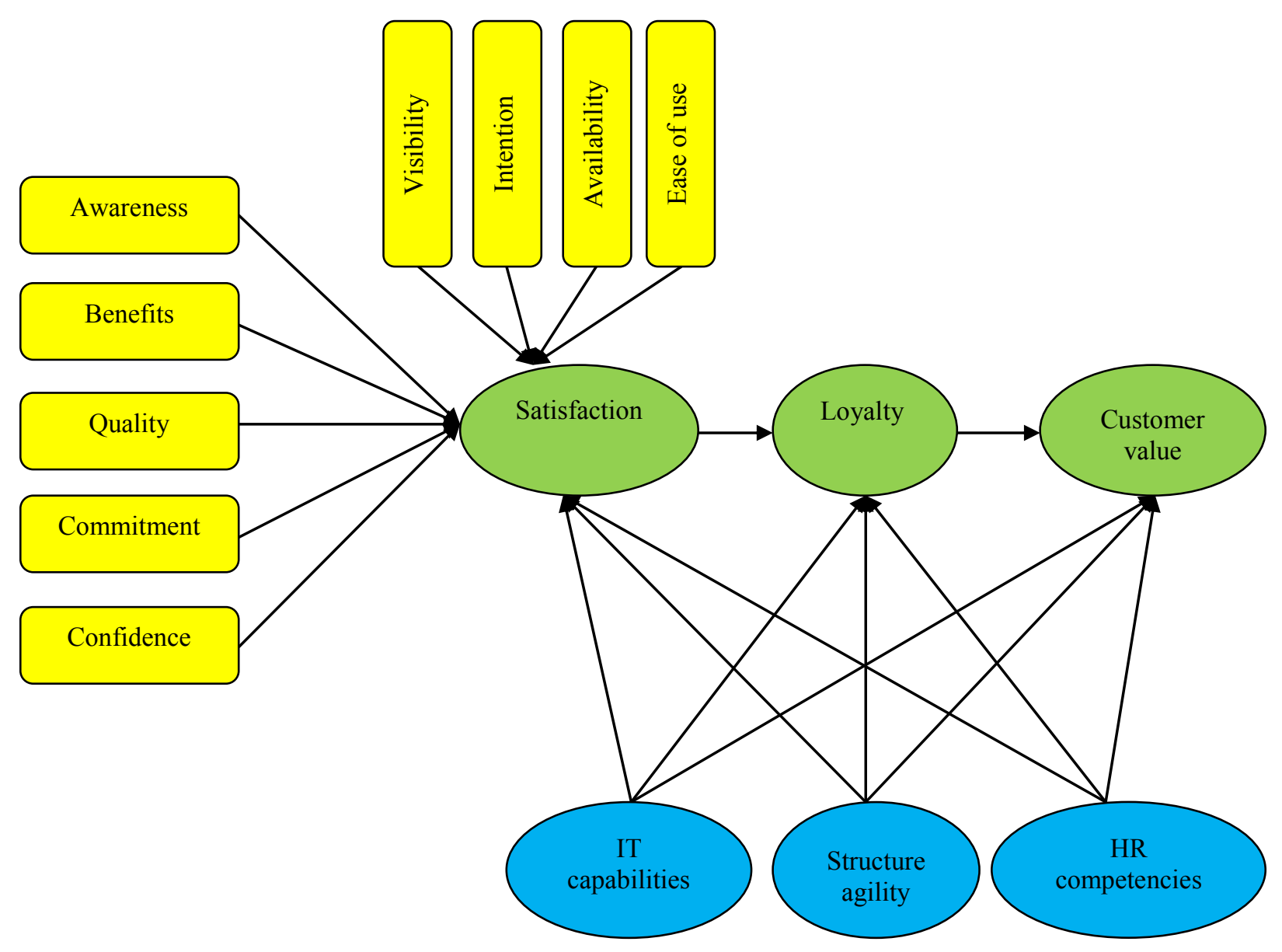

Figure 2. The proposed model. 


\section{SUMMARY AND FINDINGS}

Islamic banking marketing is an endeavor to customize the principles and approaches of marketing management and planning to the Islamic banking sector in order to create value and maintain the growth of Islamic banking industry. This research aimed at identifies basic elements and factors determining the Islamic banking marketing breakthrough in form of a conceptual model. The proposed model containing three main categories and totally 15 basic elements has been presented. At the level one category there were nine factors encompasses: Quality, Benefits, Awareness, Commitment, Confidence, Ease of use, Availability, Intention, and Visibility. Then in the level two categories there were three basic factors encompasses: customer satisfaction, customer loyalty and customer value. And finally at the level one category there were three factors encompasses: IT capabilities, Structure agility, and HR competencies. As proposed model showed these based elements and factors had a relationship that finally creates value for the customers. As practical suggestion future researchers is recommended to test and analyze the proposed model of this study in the desired banking field especially in the Islamic banks and financial institutions.

\section{References}

[1] Aghaei M., Vahedi, E.; Safari-Kahreh, M. \& Pirooz, M. (2014). An Examination of the Relationship between Services Marketing Mix and Brand Equity Dimensions. Procedia-Social and Behavioral Sciences, 109 (2014) 865-869.

[2] Aghaie, M.; Vahedi, E.; Asadollahi, A. \& Safari-Kahreh, M. (2014). An empirical Investigating to Effects of services Marketing mix on Brand Dimensions in Order to enhance brand Equity in the Tehran's Chain Stores. Research Journal of Recent Sciences, 3(2), 43-60.

[3] Chapra, M.U. (1985). Towards a Just Monetary System. Leicester: The Islamic Foundation.

[4] El Seoudi, A. W.; Mohamad, M. N.; Mohd, A. H. ; Nasohah, Z.; Alias, M. N. \& Ghani, N. A. (2012). Islamic banking marketing. Journal of Economic Theory, 6(2), 61-65.

[5] Estiri, M.; Hosseini F. \& Yazdani H. (2011). Determinants of customer satisfaction in Islamic banking: evidence from Iran. International Journal of Islamic and Middle Eastern Finance and Management, 4 (4), 295-307.

[6] Fathollahzadeh, M.; Hashemi, A. \& Safari-Kahreh, M. (2011). Designing a New Model for Determining Customer Value Satisfaction and Loyalty towards Banking Sector of Iran. European Journal of Economics, Finance and Administrative Sciences, 28, 126138.

[7] Gudarzi-Farahani, Y. and Sadr, S.M.H. (2012). Analysis of Islamic Bank's Financing and Economic Growth: Case Study Iran and Indonesia. Journal of Economic Cooperation and Development, 33(4), 1-24. 
[8] Hassan, K.M. \& Lewis M.K. (2007). Handbook of Islamic Banking. Cheltenham (UK): Edward Elgar Publishing Limited.

[9] Hennig-Thurau, T.; Gwinner, K. P. \& Gremler, D. D. (2002). Understanding Relationship Marketing Outcomes: An Integration of Relational Benefits and Relationship Quality. Journal of Service Research, 4(3), 230-247.

[10] Jamshidi, D. \& Hussin, N. (2013). Determining a Conceptual Framework for Adoption of Islamic Credit Card in Context of Malaysia. Journal of Basic and Applied Scientific Research, 3(1), 188-196.

[11] Karbhari, Y.; Naser, K. \& Shahin, Z. (2004). Problems and Challenges Facing the Islamic Banking System in the West: The Case of the UK. Thunderbird International Business Review, 46(5), 521-543.

[12] Kotler, P. \& Keller, K. L. (2009). A Framework for Marketing Management (4 ${ }^{\text {th }}$ Ed.). Pearson Prentice Hall.

[13] Memon, N. A. (2007). Islamic Banking: Present and Future Challenges. Journal of Management and Social Sciences, 3(1), 1-10.

[14] Metawa, S. A. \& Almossawi, M. (1998). Banking behaviour of Islamic bank customers: perspectives and implications. International Journal of Bank Marketing, 16(7), 299313.

[15] Safari-Kahreh, M. \& Safari-Kahreh, Z. (2012). An Empirical Analysis to Design Enhanced Customer Lifetime Value Based on Customer Loyalty: Evidences from Iranian Banking Sector. Iranian Journal of Management Studies, 5(2), 145-167.

[16] Safari-Kahreh, M.; Ahmadi, H. \& Hashemi, A. (2011). Achieving competitive advantage through empowering employees: An empirical study. Far East Journal of Psychology and Business, 3(3), 26-37.

[17] Safari-Kahreh, M.; Tive, M.; Babania, A. \& Hesan, M. (2014). Analyzing the Applications of Customer Lifetime Value (CLV) based on Benefit Segmentation for the Banking Sector. Procedia-Social and Behavioral Sciences, 109, 590-594.

[18] Safari-Kahreh, Z.; Shirmohammadi, A. \& Safari-Kahreh, M. (2012). An empirical study to analyze customer relationship management strategy using balanced scorecard. Management Science Letters, 2(5), 1603-1612.

[19] Seyed-Javadin, S. R.; Raei, R.; Iravani, M. J. \& Safari, M. (2014). An explanatory analysis to identify and prioritize the challenges of Islamic Banking implementation: the case of IR Iran. International Letters of Social and Humanistic Sciences, 24, 45-55.

[20] Seyed-Javadin, S. R.; Raei, R.; Iravani, M. J. \& Safari, M. (2014). Presenting a conceptual model to explain the role of strategic management and planning in Islamic banking competitiveness. International Letters of Social and Humanistic Sciences, 26, 46-56. 
[21] Seyed-Javadin, S. R.; Raei, R.; Iravani, M. J. \& Safari, M. (2014). Conceptualizing and Examining the Critical Success Factors for Implementing Islamic Banking System towards Banking Sector of Iran: a Mixed Method Approach. Iranian Journal of Management Studies, Article in press, available at: http://ijms.ut.ac.ir.

[22] Vayanos, P.; Wackerbeck, P.; Golder, P. T. \& Haimari, G. (2008). Competing Successfully In Islamic Banking. Booz \& Company.

[23] Vilares, M. \& Coelho, P. S. (2003). The employee-customer satisfaction chain in the ECSI model. European Journal of Marketing, 37(11/12), 1703-1722. 